\title{
Some environmental aspects of marine hydrocarbon bacteriology
}

\author{
G. D. Floodgate \\ School of Ocean Sciences, Marine Science Laboratories, University of Wales at Bangor, Gwynedd LL59 5EY, United Kingdom
}

\begin{abstract}
This paper reviews some of the field aspects of hydrocarbon bacteriology in the marine environment. The first section recapitulates the current position with regard to the input of polluting oil into the sea and the main environmental factors which govern the rate of oil breakdown. The second deals with the 1991 oil spill during the Gulf War and what is known about the bacteriology of that area, together with some jecent data from Japan. Thirdly a critical review of the theory and practise of bioremediation as applied to contaminated beaches in several parts of the world leads to the conclusion that there are still a lot of unknown variables that must be better understood before the method can be of widespread use. Finally a short review of gaseous hydrocarbons in the sea suggests that methane from petrogenic or biogenic sources is of both practical and theoretical interest and importance for the future.
\end{abstract}

KEY WORDS: Bacteria $\cdot$ Hydrocarbons - Marine pollution

\section{SUMMARY OF CURRENT POSITION}

In the years since the Torrey Canyon disaster in 1967, a great deal has been learnt about both the chemistry and microbiology of hydrocarbon metabolism and the fate of oil spilt in the environment. The work has been set out in detail in Petroleum Microbiology (Atlas 1984) and recently updated by Leahy \& Colwell (1990). The specifically marine aspects were reviewed by Floodgate (1984). Greatest attention has been paid to the spillage of crude oil due to the wrecking of tankers since these events are the most dramatic and newsworthy, but it is important to take into account the effect of chronic low level pollution of refined products such as bunker fuel and engine oil as well. Owing to greater public awareness and greater technical control of oil transport and handling, the amount of oil in the oceans is decreasing. Figures published by the International Maritime Organisation (IMO) show an estimated decrease of $60 \%$ in oil pollution due to shipping operations from $1.4 \times 10^{6}$ tonnes in 1981 to $5.8 \times 10^{5}$ tonnes in 1989 (cited by Ambrose 1991). A fall in the number of tarballs suggests that a similar reduction may be taking place here too (Holdway 1986). A recent survey reports a reduction in UK waters (Anonymous 1993a). The downward trend has been recently confirmed by the Group of Experts on Scientific Aspects of Marine Pollution (GESAMP 1993) who estimate a fall in the total tonnage of oil from all sources entering the marine environment from 3.3 million tonnes in 1981 to 2.35 million tonnes in 1990. Input from shipping has declined, but there is evidence that land based sources may have been underestimated in the past, and that local enclosed and semi-enclosed areas may receive greater pollution than global estimates would indicate. Tanker accidents spilling crude make up only $5 \%$ of the total, while the fraction made up by lubricants and other processed oils is increasing. Greater scientific attention will have to be addressed to these products in the future.

Once in the sea, the oil begins to change under the influence of physical, chemical and biological factors. Evaporation may remove up to $30-40 \%$ of the oil in a few days depending upon the temperature and the composition of the oil mixture. The surface tension of the sea water and the oil will determine how quickly the oil spreads to become a film which may be only microns thick. Wind and wave action tend to the formation of 'mousse' which is a stable water-in-oil emulsion. Such changes due to climatic factors are known 
as weathering, though some authors also include the changes caused by biological activity within the term. Increasing weight due to the adhesion of particulates changes the specific gravity to a value greater than water, so that the oil sinks down the water column and in shallow seas will deposit on the bottom. Wave action and sediment movement roll up small amounts of partially degraded oil into tar balls which vary in size from a millimetre to large pieces some centimetres across and weighing several kilograms.

Changes in the composition of weathered oil are mainly brought about biologically, and the most active of agents causing these changes are the bacteria. Marine oil degraders are universally distributed being found in inshore waters, shelf seas, the deep oceans including the abyss, beaches and bottom sediments. The bacteria belong to a wide range of genera including Vibrio, Pseudomonas, Acinetobacter, Achromobacter and Corynebacteria. In nature, the degradation may well be effected by a 'community' of bacterial strains acting in concert or sequence, rather than the single strains that are the usual subject of laboratory studies. For example, Tagger et al. (1990) found that only 2 strains of a group of 9 , isolated from marine sediment, were able to grow on napthalene as sole carbon source, but the remaining 7 used metabolic intermediates.

There are a number of environmental factors which govern the rate at which the oil breaks down. Molecular oxygen is generally required since it is the terminal electron acceptor for many degradative pathways, and is inserted into the molecule as a first step in the case of n-alkanes (Singer \& Finnerty 1984). The oxidation reduction potential in sea water is generally poised so that oxygen partial pressure does not become rate limiting. However, it is well documented that fine sediments which contain organic matter become anaerobic, and that oxidation continues using a series of electron acceptors which function within a given range of oxidation/reduction potentials. A number of workers have demonstrated anaerobic oxidation of several hydrocarbons by bacteria isolated from marine environments under laboratory conditions. For example, Aeckersberg et al. (1991) found a small sulphate reducer which used n-hexadecane as electron donor with the formation of sulphide. The organism grew on alkanes from $\mathrm{C}_{12}$ to $\mathrm{C}_{20}$ and several fatty acids. Similarly the anaerobic oxidation of 1-n-heptadecane was shown by a denitrifying pseudomonad, which also formed an emulsifying agent anaerobically (Gillewicz et al. 1991). The breakdown of toluene was demonstrated under sulphate reducing conditions by Beller et al. (1992), who pointed out that iron greatly increased the toluene degradation rate. Clearly anaerobic attack has been convincingly shown in the laboratory, but the extent to which the mechanism operates in the marine field remains unknown. Certainly once oil penetrates deeply into sediment, particularly low energy, muddy sediments, it appears to stay a long time (Burns et al. 1993). Possibly the oil replaces the interstitial water containing the electron acceptors, or there is a lack of some other factor such as iron or nutrient. The latter theory is strengthened by the work of Scherrer \& Mille (1989) who reported that the slow biodegradation of oil trapped in peaty mangrove soils could be hastened by the addition of oleophilic fertilisers. In contrast, Mille et al. (1988) investigated the relationship between the dissolved oxygen in overlying water and the degradation of various oils and pure hydrocarbons in sediment. They found that oxidation was marked when the oxygen concentration in the water was 8 ppm with a redox potential of $+150 \mathrm{mV}$. Breakdown slowed by a factor of 2 to 3 when the oxygen concentration and potential fell to $2-3 \mathrm{ppm}$ and $+30 \mathrm{mV}$ respectively, and ceased at concentrations of $0.2-0.3 \mathrm{ppm}$ and $-180 \mathrm{mV}$. These findings suggest that oxygen concentration and low redox potential per se are the cause of the lack of degradation.

The main factor limiting the rate of mineralisation in the water column is most frequently the concentration of available nitrogen. In the Irish Sea, approximately $4 \mathrm{mM}$ of nitrogen were required for the breakdown of $1 \mathrm{mg}$ of crude oil i phosphorus did not become limiting down to a minimum P/N ratio of 0.02 (Gibbs 1975). Since the concentration of nitrogen in the Irish Sea is around 8 to $9 \mathrm{mM}$ and algae compete for available supplies, the rate of oil loss by bacterial action depends on the rate of nitrogen regeneration. As well as affecting the evaporation rate, temperature governs the rate of chemical reaction. $A Q_{10}$ of 2.7 was found for the Irish Sea for water temperatures of between 4 and $14^{\circ} \mathrm{C}$ (Gibbs et al. 1975).

\section{BACTERIOLOGY OF SOME RECENT OIL SPILLS}

Because of their often catastrophic effect on the environment, major oil spills bring together teams of oceanographers, chemists and biologists (with the necessary funding) in a way that chronic pollution rarely does. The disaster is therefore softened slightly by some advance in our knowledge of environmental effects. Unfortunately, bacteriologists are rarely included in the scientific teams, although it is well recognised that bacteria are the ultimate agents of oil breakdown, and the gateway by which some of the carbon and energy contained in the oil finds its way into the upper echelons of the food web by way of protozoa, zooplankton and meiofauna. However, bacteriological details have emerged in a few recent reports, and 
these are reviewed below with regard to the Arabian Gulf and Japanese waters.

\section{The Arabian Gulf oil spill}

During the Gulf War of 1991, something in excess of 1 million tonnes of crude and processed oils was released into the waters of the Gulf either through deliberate destruction of oil facilities or from shipping losses, making the world's largest oil spill to date. Because of the war situation, early scientific response was impossible. However, as soon as was practicable, international scientific teams began to address the situation. There were 2 main efforts. The first centred around the cruises of the research vessel 'Mt Mitchell', under the aegis of National Oceanic and Atmospheric Administration of the USA (NOAA), Regional Organisation for the Protection of the Marine Environment (ROPME), various UN agencies and the Saudi Arabian authorities. The second, begun some time after the spill, was the setting up and continual monitoring of a Wildlife Sanctuary for the Gulf Region by the European Union (EU) and the National Commission for Wildlife Conservation and Development of the Saudi Arabian Government (NCWCD) (Krupp \& Jones 1993). The Sanctuary, which extends northward from the southern limit of the major pollution, is situated in the Dawhat ad Dafi and Dawhat ad Musallamiya area, near Jubail, Saudi Arabia, and includes a number of the offshore islands. Monitoring the recovery of the area is to continue indefinitely. Much of the information from these efforts, as well as other data, can be found in Volume 27, 1993, of the Marine Pollution Bulletin which is entirely devoted to the Gulf Spill, and in the Final Publications for the Gulf Sanctuary, shortly to be published by the Senckenberg Museum, Frankfurt a. M., Germany, on behalf of the EU and NCWCD in Courier Forschunginstitut Senckenberg. Unfortunately neither of these extensive sets of reports is concerned to any extent with microbiology.

Since a significant proportion of the world's crude oil supply passes along the Gulf, it would be anticipated that the area would be subject to a substantial chronic pollution. However chemical analysis of land based pollution sources by the Kuwait Action Plan (KAP) States (ROPME 1986), of hydrocarbons in the water column and sediments of the Shatt Al-Arab river region and the northwest part of the Gulf (DouAbul 1984, DouAbul et al. 1984, DouAbul \& Al-Saad 1985, Grimalt et al. 1985, Al-Saad 1987), and of surface sediments off Kuwait (Zarba et al. 1985) all demonstrated unexpectedly low loadings of hydrocarbons. The low levels were attributed to rapid breakdown due to high air and water temperatures, intensive solar radiation, rapid bacterial action and high water mixing rates. These results have been recently confirmed by Mille et al. (1992), Badawy et al. (1993) and Al-Saad \& AlTimari (1993). Odd/even carbon chain length ratios show that the hydrocarbons originate in algae and plants as well as from anthropogenic sources. An Indian investigation (Sen Gupta et al. 1993) concluded that in spite of the huge volume of oil released during the war, very little found its way out of the Gulf into the Arabian Sea. It is reasonable to conclude therefore that the epuration mechanisms of the Gulf are rapid.

Pre-spill estimates of bacterial numbers are sparse. Enumeration of hydrocarbon utilisers in the Khor AlZubair region of the Shatt Al-Basrah in the northwestern Gulf showed around $2.0 \times 10^{4}$ organisms per litre of sea water and around $7.0 \times 10^{4}$ bacteria per kilogram wet muddy sand. Gram negative organisms belonging to the genera Pseudomonas, Vibrio, Flavobacter, Acinetobacter, Aeromonas and Enterobacter predominated. The only Gram positive organisms belonged to the genus Bacillus (Shamshoon et al. 1990). Some preliminary investigations by the present author (Floodgate 1994) demonstrated the presence of hydrocarbon degrading bacteria in samples from water, sand and mud from several collecting points within the Wildlife Sanctuary and indicated that protozoa very actively grazed the bacteria keeping total numbers low.

An unusual feature of the microbiology of the beached oil in the Gulf was reported by Hoffman (1994). He showed that the unpolluted areas of the upper intertidal zone were dominated by extensive cyanobacterial mats of several types. The oil severely affected the mats so that most of the cyanobacteria died. Two years later the mats had not recovered in those areas where degraded tarry oil was still visible. In those low energy zones where the tar was covered by a layer of newly deposited fine sediment recolonisation was rapid. The tarry layers in these areas dry out and tended to break up into polygonal lumps which were sometimes lifted off by the tide so exposing the less well degraded oil beneath. Whether this is assisted by buoyancy changes caused by the blue green layer is not clear. An anoxic layer develops beneath the procaryotic mats which become colonised by purple sulphur bacteria which appear to utilise the sulphide formed by sulphate reducing bacteria degrading organic matter within the mat. Thus the surface of the tarry lumps exhibit an interesting and unexpected microbial ecosystem.

In many areas of the Sanctuary, the oil has penetrated to a depth of $40 \mathrm{~cm}$ or more. This oil is virtually unchanged and is slowly leaching out of the fine mud sediments. Whether the lack of degradation is due to the absence of oxygen or of nutrients or both has yet to be established. 


\section{Japanese waters}

A comparison of the hydrocarbonoclastic bacteria of 2 contrasting areas of Japanese waters yielded some interesting results (Kimura et al. 1989). They observed that the population from Bisa-Seto, an area badly polluted with heavy oil, was dominated by strains fromn the genus Corynebacteria, whereas the flora of unpolluted Hibiki-Nada contained Pseudomonas as well as Corynebacteria. This is unusual in that most reports list Gram negative species as the predominant strains in oil oxidation in the sea (Floodgate 1984). Furthermore, they found that the oil degrading activity of the coryneforms was much higher than that of the pseudomonads regardless of the place of origin. On average, the coryneforms degraded $21.6 \%$ of the oil whereas the Gram negatives broke down only $14.1 \%$. The origins of the difference between this particular area and other places is not clear. In contrast, Venkateswaran et al. (1991) examined the distribution and oil degrading potential of bacteria in northeastern Japanese coastal waters and found that they were low. They were able to identify only $61 \%$ of the strains: Acinetobacter, Psychrobacter and a Gram positive coccus predominated.

\section{BIOREMEDIATION}

Bioremediation may be defined as a field procedure designed to increase the rate of natural degradative processes, by changing the rate limiting factor to a faster one. Such a definition implies that the rate limiting factor is known and can be changed. This is not always possible. When oil was added to a cascade microcosm which was maintained at a temperature low enough to produce an ice covering, several of the bacteriological indicators of degradation were noted. An initial drop in total heterotrophs suggested the usual toxic effect of the lighter ends. An increase in the density and proportion of oil degraders was noted in $2 \mathrm{~d}$ providing evidence of the capacity of indigenous organisms to attack oil. Nevertheless chemical change was very slight (Siron et al. 1993). It is reasonable to assume that the limiting factor was the temperature characteristics of the enzymes which carry out the initial oxidative steps. The only bioremediation process that could be effective here is to isolate or engineer a bacterium with the necessary low temperature enzymes, if that is possible. These finding suggest that caution should be exercised in considering the possibility of using bioremediation especially in sensitive areas such as the Antarctic or Arctic regions.

To be of real value, the bioremediation must speed up the natural process significantly, particularly as regards the more recalcitrant material. Simply increas- ing the rate of rapidly lost alkanes is not greatly advantageous. Indeed since it has been shown that the loss of some ring compounds is enhanced by co-oxidation involving alkanes, very rapid removal of the simpler compounds may in fact slow up the rate of loss of the aromatics

Clearly different bioremedial techniques are required for different marine situations, such as sunken oil or beach substrata. The primary problem is to find ways of keeping the added culture or chemicals in close contact with the hydrocarbon for a period of days or weeks.

In order to know whether a given procedure has in fact enhanced degradation, it is necessary to know the oxidation rate without the treatment or alternatively to use a control area, and to be certain that any loss of hydrocarbons detected is not due to abiotic processses (Shannon \& Unterman 1993). Since no 2 areas of shoreline are exactly alike, the choice of whether a selected area is a good control is largely a matter of subjective judgment rather than scientific rigor

There is very little kinetic information on degradation rates at sea, on the beaches or even in the laboratory. Indeed, documentation concerning the relative rate of the physical, chemical and biological processes for any kind of oil breakdown within the marine environment is scarce. Using laboratory data and archive material on nitrogen regeneration, Gibbs (1975) calculated that the rate of bacterial breakdown of crude oil in the Irish Sea to be of the order of 11 to $30 \mathrm{mg}$ oil m$^{-3}$ $\mathrm{yr}^{-1}$ between 4 and $14^{\circ} \mathrm{C}$. Direct measurement of rates in the marine environment is also difficult, not least because of the problem of obtaining a representative sample This is particularly acute on heterogenous beaches. The amounts of oil found in samples from even a fairly small beach area tend to have a markedly skewed distribution, which complicates statistical treatment.

There is also the question of the kind of measurement that is taken to indicate oil loss, since oil is a variable mixture of a large number of substances. Direct chemical methods are to be preferred to indirect ones which rely, for example, on the estimation of an increase in bacterial numbers, or mineralisation potentials. The ratio between quickly degraded substrates and the slowly mineralising isoprenoids such as pristane and phytane and hopane have also been used successfully. Fortunately there have been a number of recent developments which has increased the effectiveness and accuracy of measuring oil loss and bacterial growth. GC-MS machines have become smaller and cheaper, uptake kinetics using radio labelled substrates are commonplace and flow cytometry is more easily available (Robertson \& Button 1989, Hostettler et al. 1992, Burns 1993). 


\section{Addition of bacteria}

The high frequency with which bacteria with the enzymes needed to attack alkanes are found in the sea means there is no point in adding a prepared culture to remove them. Any added bacteria ought to target the more slowly degraded substances. At this point it is useful to recall Alexander's comments on the nature of recalcitrance (Alexander 1975/6). It is important to avoid the microbiological heresy that asserts that bacteria can defy the laws of chemistry and break down everything! The decomposition of some large molecules requires considerable energy, and the energy balance must in the end be to the organisms' advantage. All the non-environmental factors involved in degradation are genetically controlled, and the genetic information must be contained within either a community of several organisms or within one strain either chromosomally or as plasmids. Probably because natural seeps have been releasing oil into the sea for a very long time, genetically competent strains or communities are easily obtained by careful enrichment, and the advantages gained from DNA manipulation are small. There are however both practical and theoretical problems in introducing 'foreign' strains into a natural situation, especially as it is impossible to completely control the organisms once they are released into the environment. The protocols required and the effectiveness of some commercial products have been discussed by Venosa et al. (1991a, b). The use of bacterial releases for bioremediation is likely to be used only in exceptional cases, i.e. enclosed areas, if at all.

\section{Enhancing environmental nutrients}

Practically in a marine context, bioremediation generally involves increasing the available nutrient, especially nitrogen and phosphorus. A characteristic of a good bioremediation agent is that it should add nitrogen and phosphorus in adequate quantity and that the nutrients should remain with the oil and not leak extensively into the surrounding water, and be lost. Ideally the nutrients should partition into the oil, that is they should be oleophilic, and so be near to the bacteria investing the oil droplets. Capsulated or granular forms of nutrient package are easily lost unless the granules are retained in porous containers, and so may only be used on low energy beaches. An alternative approach is to incorporate the nitrogen into a dispersant so that each droplet of dispersed oil carries with it a supply of nutrients. Yet another approach under investigation is to use a matrix into which nitrogen and phosphate is incorporated: the matrix then absorbs the oil.
Only a little thought seems to have been given to the dose rate and the optimum ratio of added nutrient to oil needed to realise maximum loss rate. As already stated, $4 \mathrm{mM}$ nitrogen were required to breakdown $1 \mathrm{mg}$ crude oil in the Irish Sea (Gibbs 1975). Fusey \& Oudot (1984) suggested that the effectiveness of nutrient enhancement is dependent upon the level of oil contamination and varies with the degree of weathering, while Button et al. (1992) have demonstrated that the interaction between bacteria and dissolved and beached hydrocarbons is not adequately represented by a simple model.

\section{Results to date}

Enthusiasm for marine oil bioremediation varies from high among industrialists anxious to see the results of an accident removed from public gaze to none at all from conservationists who see bioremediation as yet another intrusion into natural processes. Unfortunately, scientific judgement on bioremediation has been clouded by emotional, commercial and litigation considerations (e.g. Anonymous 1993b). There is little doubt that bioremediation has had a significant degree of success in cleaning industrial land sites (Atlas 1991). There is not much to be gained in trying to use the method in the open sea, but beaches, which vary of course from fine mud to solid rock, and therefore to some extent resemble land sites, present a series of problems which have not yet been solved.

Most of field experiments on bioremediation have been carried out in North America, with the most extensive trials being made on the beaches badly oiled after the 'Exxon Valdez' oil spill (Hoff 1993). Most experiments have involved the addition of nutrients either as pellets or as a product of the Elf Aquitaine company called INIPOL EAP22. This is an oleophilic micro-emulsion containing lauryl-ether-phosphate. There has been some concern expressed about the possible toxicity of this surfactant (Bragg et al. 1993). Urea dissolved in salt solution as nitrogen source is encapsulated in oleic acid as external phase.

Laboratory trials of INIPOL using a light condensate as oil source were carried out by Lee \& Levy (1987). These authors noted that there was a marked increase in the heterotrophic count in the early stages although the oil itself was unchanged. They attributed this to the bacteria growing on the oleic acid and sparing the hydrocarbons. Similar studies by Rivet et al. (1993), using hexadecane as carbon source and a marine isolate, again showed a rapid increase in bacterial numbers due to the oxidation of the fatty acid during the first $24 \mathrm{~h}$. Hexadecane degradation took place after $50 \mathrm{~h}$ incubation and reached $40 \%$ after $360 \mathrm{~h}$. In a field 
experiment, North Sea crude was deposited in known quantity on pieces of slate which were then placed in trays on a low energy beach in the Menai Strait, Wales, UK. Half the slates were treated with INIPOL, and all were examined after several days. No difference in oil loss was detected between the 2 sets (Latchford pers. comm.).

Following the 'Exxon Valdez' spill, attempts were made to clean up selected beaches under the general overall supervision of the American authorities. There have been a number of claims that the attempt has been successful to a greater or lesser degree. A marked reduction in beached oil following the addition of INIPOL EAP22 during 1989-1990 has been claimed by a substantial team of workers (Chianelli et al. 1991). Other field studies, using periodic additions of nutrients, showed a marked increase in total heterotrophic count, while chemical analysis and radiotracer studies indicated removal of the oil residues (Lee \& Levy 1989, 1992). Another investigation was carried out by Lindstrom et al. (1991) on the effect of INIPOL and Customblen on 3 'Valdez' oil contaminated beaches. The latter fertiliser is a slow release formulation of soluble nutrients enclosed in poly merised vegetable oil. The first beach had surface oil only, the second oil on the surface and in the subsurface, while the third had subsurface oil only. Customblen was added to all sites and INIPOL only where there was surface oil. Bacterial numbers and degradation potential were measured in terms of hexadecane and phenanthrene mineralisation. Surface microbial numbers did not differ between treated and untreated plots after the first application, but there was a subsurface difference. The second application some weeks later resulted in activity in both subsurface and surface plots in several areas in relation to control sites. The authors conclude that the elevated mineral potentials and increased bacterial numbers showed that degradation was enhanced even though they did not carry out direct chemical analyses. In contrast, other observers working in the Prince William Sound area, and around the same time, concluded that 'natural cleaning appeared to be dominated by wave action during storms' (Jahns et al. 1991). It has also been claimed that surfactants formed by Pseudomonas aeruginosa were effective in cleaning gravel beaches following the 'Exxon Valdez' spill (Harvey et al. 1990). Other trials in the USA following spills at Seal Beach (California), Pralls Island (New Jersey), Apex Barges and Mega Borg (Gulf of Mexico) were ambiguous in their resuit, sometimes due to poor experimental design (Hoff 1993).

INIPOL EAP222 was also used to clean up a spill at Spitzbergen (Sveum 1987). Although an acceleration in the disappearance of the alkanes was noted, the general conclusion was that the physical processes were the dominant ones in oil removal.

Pelleted nutrients contained in porous bags have been used in small scale experiments. Satisfactory results were only obtained in microcosms; in the field the nutrients were rapidly lost to the environment and only very slightly augmented activity was noted (Latchford pers. comm.). Lee \& Levy (1989) found however that they could obtain satisfactory results when they mixed agricultural fertiliser with sand in bags with a $264 \mu \mathrm{m}$ mesh. Using a hydrophobic fertiliser, F-1, which is a modified urea-formaldehyde polymer containing nitrogen and phosphorus, Rosenberg et al. (1992) cultivated a strains of bacteria which both grew on oil and utilised the fertiliser which remained at the oil water interface and so close to bacteria adhering to oil droplets. Using this combination on a sandy Israel beach they found a marked stimulation of hydrocarbon breakdown. This was modified by temperature as considerable differences were found between summer and winter conditions.

Some clean up trials were also attempted at several sites within the Wildlife Sanctuary for the Gulf Region (Watt et al. 1993). All were mechanical and either employed sea water applied at high or low pressure or rotational ploughing and water flushing combined, or rotational water jets. Quantities of oil were released from the sediments and collected by booms. In addition the breakup of the sediment surface allowed oxygen to penetrate to increase bacterial oxidation. Success was measured by the amount of oil removed and the rate of animal recolonisation rather than chemical or microbiological means

It would appear then that bioremediation in the marine environment may be a useful tool when the conditions are propitious. However the general question of the value of bioremediation as a practical large scale procedure at the present 'state of the art' was addressed by Owen (1991). His conclusion was that too many unanswered questions about cost effectiveness and environmental concerns remain for bioremediation to be recommended for use other than experimentally'.

\section{GASEOUS HYDROCARBONS}

The major non-polluting hydrocarbon found in the sea is methane gas. The origin, fate and bacteriology of this simple hydrocarbon are increasingly being recognised as interesting not least because the gas has a greenhouse effect almost 4 times greater than carbon dioxide. Methane is found in surprisingly high concentrations in the water column, and the atmosphere (Hovland \& Judd 1988). The oil industry has long been 
aware of the dangers of pockets of methane at very high pressure which exist at considerable depths. In addition, shallow gas deposits, that is down to $1000 \mathrm{~m}$ into the sediment, interfere with high resolution acoustic profiling because the gas is in sufficiently high concentration to form bubbles which scatter the sound signal and so cause 'acoustic turbidity'. These gassy sediments have changed geophysical properties which alter their engineering characteristics. The origins of the gas may be biogenic or petrogenic, i.e. formed by methanogenic bacteria from a small set of organic substrates or by diagenic geochemical processes deep in the sea floor (Floodgate \& Judd 1992). The bacteria concerned belong to a group known as the archaebacteria which are very strongly anaerobic and contain a number of very unusual lipids, a feature that can be used to determine their frequency in the mud (Martz et al. 1983, Smith \& Floodgate 1992). Gas which has arisen from biological activity may be distinguished from that formed petrogenically by determining the stable isotopic ratios, particularly ${ }^{13} \mathrm{C} /{ }^{12} \mathrm{C}$. The results are often ambiguous due to mixing of gas from different sources and by isotope discrimination by methane oxidising bacteria.

Plumes of gas escaping from these shallow deposits into the water column have been reported from shallow shelf seas such as found off the Baltic coast of Denmark, the North Sea and the Adriatic (Hovland \& Judd 1988). The areas surrounding the gas plumes appear to have a modified biology, which may be attributed to bacterial action (Dando et al. 1991). Two methane oxidation mechanisms are known; one aerobic and the other anaerobic apparently using sulphate as terminal electron acceptor (Rudd \& Taylor 1980). Organisms belonging to the latter group may be responsible for the removal of methane as it migrates through the sediment. Associated with oxidation in as yet an unknown way is the formation of 'bioconcrete', a hard carbonaceous rock, mostly magnesium rich calcite, dolomite, and aragonite which appears in the Baltic and elsewhere (Hovland \& Judd 1988). Because of the unusual features connected with both the formation and the oxidation of methane, and the implications for engineers, biologists and biotechnologists, the future study of the methane cycle will yield far reaching results.

\section{LITERATURE CITED}

Aeckersberg F, Bak F, Widdel F (1991) Anaerobic oxidation of saturated hydrocarbons to $\mathrm{CO}_{2}$ by new type of sulphate reducing bacteria. Arch Microbiol 156:5-14

Alexander M (1975/76) Environmental and microbiological problems arising from recalcitrant molecules. Microb Ecol 2:17-27

Al-Saad HT (1987 Distribution of polycyclic aromatic hydrocarbons (PAH) in surficial sediments from Shatt-Al-Arab river and north-western region of Arabian Gulf. Mar Pollut Bull 18:248-251

Al-Saad HT, Al-Timari AAK (1993) Seasonal variations of dissolved n-alkanes in water marshes of Iraq. Mar Pollut Bull $26: 207-212$

Ambrose P (1991) Oil pollution on the decrease. Mar Pollut Bull 22:262

Anonymous (1993a) Oil spills decreasing in the UK. Mar Pollut Bull 26:663

Anonymous (1993b) Exxon challenge US Government Valdez spill data. Mar Pollut Bull 26:296

Atlas RM (1984) Petroleum microbiology. Macmillan, New York

Atlas RM (1991) Microbial hydroca:bon degradation - bioremediation of oil spills. J Chem Technol Biotech 52 149-156

Badawy MI, Al-Mujainy S, Hernandey MD (1993) Petroleum derived hydrocarbons in water, sediment and biota from Mina-al-Fahal coastal waters. Mar Pollut Bull 26:457-460

Beller HR, Grbic-Galic D, Reinhard M (1992) Microbial degradation of toluene under sulphate reducing conditions and the influence of iron on the process. Appl environ Microbiol 58:786-793

Bragg JR, Prince RC, Harner EJ, Atlas RM (1993) Bioremediation effectivenesss following the Exxon Valdez spill. In Proceedings of the 1993 Oil Spill Conference. Washington, API, p 435-447

Burns KA (1993) Analytical methods used in oil spill studies. Mar Pollut Bull 26:68-72

Burns KA, Garrity SD, Levings SC (1993) How many years until mangrove ecosystems recover from catastophic oil spills? Mar Pollut Bull 26:239-248

Button DK, Robertson BR, McIntosh D, Juttner F (1992) Interactions between marine bacteria and dissolved phase and beached hydrocarbons after Exxon Valdez oil spill. Appl environ Microbiol 58:243-251

Chianelli RR, Aczel T, Bare RE, George GN, Genowitz MW Grossman MJ, Haith CE, Kaiser FJ, Lessard RR, Liotta R, Mastracchio RL, Manak-Bernero V. Prince RC, Robbins WK, Stiefel EI, Wilkinson JB, Hinton SM, Bragg JR, McMillen SJ, Atlas RM (1991) Bioremediation technology development and application to the Alaskan spill. In: Proceedings of the 1991 Oil Spill Conference. Washington API, p 549-555

Dando PR, Austen MC, Burke A, Kendell MA, Kennicutt MC Judd AG, Moore DC, O'Hara SCM, Schmaljohann R, Southward AJ (1991) Ecology of a North Sea pockmark with an active methane seep. Mar Ecol Prog Ser 70:49-63

DouAbul AAZ (1984) Petroleum residues in the waters of Shatt-Al-Arab river and northwest region of Arabian Gulf Environ Internat 10:265-267

DouAbul AAZ, Al-Saad HT, Darmoian SA (1984) Distribution of petroleum residues in surficial sediments from Shatt-AlArab river and north west region of the Arabian Gulf. Mar Pollut Bull 15:198-200

DouAbul AAZ, Al-Saad HT (1985) Seasonal variation of oil residues in waters of Shatt-Al-Arab river, Iraq. Water Air Soil Pollut 24:237-246

Floodgate GD (1984) The fate of petroleum in marine ecosystems. In: Atlas RM (ed) Petroleum microbiology. Macmillan, New York, p 355-379

Floodgate GD (1994) The bacteriology of oil epuration in the Wildlife Sanctuary for the Gulf Region. In: Abuzinada AH Krupp F (eds) Courier Forschunginstitut Senckenberg, in press

Floodgate GD, Judd AG (1992) The origins of shallow gas Cont Shelf Res 12:1145-1156 
Fusey P, Oudot J (1984) Relative influence of physical removal and biodegradation in the depuration of petroleum contaminated sea shore sediments. Mar Pollut Bull 15 . $136-141$

GESAMP (Joint Group of Experts on Scientific Aspects of Marine Pollution) (1993) Impact of oil and oil related chemicals and wastes on the marine environment. Cited in Mar Pollut Bull 26:471-472

Gibbs CF (1975) Quantitative studies on marine biodegradation of oil. I. Nutrient limitation at $14^{\circ} \mathrm{C}$. Proc R Soc Lond B 188:61-62

Gibbs CF, Pugh KP, Andrews AR (1975) Quantitative studies on marine biodegradation of oil. II. Effects of temperature Proc R Soc Lond B 188:83-94

Gillewicz M, Monpert G, Acquaviva M, Mille G, Bertrant JC (1991) Anaerobic oxidation of 1-n-heptadecane by a marine denitrifying bacterium. Appl Microbiol Technol 36: $252-256$

Grimalt J, Albaiges $J$, Al-Saad HT, DouAbul AAZ (1985) $\mathrm{n}$-Alkane distribution in surface sediments from Arabian Gulf. Naturwissenschaft 72:25-37

Harvey S, Elasvii I, Valdes JJ, Kamely D, Chakrabarty AM (1990) Enhanced removal of Exxon Valdez spilled oil from Alaskan gravel by microbial surfactant. Biotechnol 8 : $228-232$

Hoff RZ (1993) Bioremediation: an overview of its development and use for oil spill cleanup. Mar Pollut Bull 26 . $476-481$

Hoffmann L (1994) Recolonisation of the intertidal flats by microbial mats after the Gulf War oil spill. In: Abuzinada AH, Krupp F (eds) Courier Forschunginstitut Senckenberg (in press)

Holdway P (1986) A circumnavigational survey of marine tar. Mar Pollut Bull 17:374-377

Hostettler FD, Rapp JB, Kenvolden KA (1992) Use of geochemical biomarkers in bottom sediment to track oil from spill in San Francisco Bay, California. Mar Pollut Bull 24 $15-20$

Hovland M, Judd AG (1988) Seabed pock marks and seepages. Graham and Trotman, London

Jahns HO, Bragg JR, Dash LC, Owens EH (1991) Natural cleaning of shore lines following the Exxon Valdez spill In: Proceedings of the 1991 Oil Spill Conference. API Washington, p 167-176

Kirnura B, Murakami M, Fujisawa $H$ (1989) Characterisation and oil degrading activity of heavy oil degrading bacteria isolated from sea water of oil polluted Bisa-Seto and oil unpolluted Hibiki-Nada. Jap Soc sci Fish 55 $1091-1095$

Krupp F, Jones DA (1993) The creation of a Marine Sanctuary after the 1991 Gulf war oil spill. Mar Pollut Bull 27: $315-323$

Leahy JG, Colwell RR (1990) Microbial degradation of hydrocarbons in the environment. Microbiol Revs 54:305-315

Lee K, Levy EM (1987) Enhanced biodegradation of light crude oil in sandy beaches. In: Proceedings of the 1987 Oil Spill Conference. API, Washington, p 411-416

Lee K, Levy EM (1989) Enhancement of the natural biodegradation of condensate and crude oil on beaches of Atlantic Canada. In: Proceedings of the 1989 Oil Spill Conference. API, Washington, p 479-486

Lee K, Levy EM (1992) Microbial degradation of petroleum in an intertidal beach environment - in situ sediment enclosure studies. In: Marine ecosystem enclosed experiments. Proceedings of a symposium held in Beijing, Peoples' Republic of China, 9-14th May 1987. IDRC, Ottawa, p $140-155$
Lindstrom JE, Prince RC, Clark JC, Grossman MJ, Yeager TR, Braddock JF, Brown ET (1991) Microbial populations and hydrocarbon degradation potentials in fertilised shoreline sediments affected by TN Exxon Valdez oil spill. Appl environ Microbiol 57:2514-2522

Martz RF, Sebacher DI, White DC (1983) Biomass measurements of methane forming bacteria in environmental samples. J microbiol Meth 1:53-61

Mille G, Mylyono M, Jammal TEl, Bertrand JC (1988) Effects of oxygen on hydrocarbon degradation studies in vitro in surficial sediments. Estuar coast Shelf Sci 27:283-293

Mille G, Rive L, Jawad AI, Bertrand JC (1992) Hydrocarbon distribution in low polluted surface sediment from Kuwait, Bahrain and Oman coastal zones (before the Gulf war). Mar Pollut Bull 24:622-629

Owen D (1991) Bioremediation of marine oil spills; scientific validity and operational constraints. In: Proceedings of the Fourteenth Arctic and Marine Oil Spill Program, Technical Seminar, Vancouver, June 1991. Environment Canada, p $119-130$

Rivet L, Mille G, Basseres A, Ladousec A, Gerin C, Acquaviva $M$, Bertrand JC (1993) n-Alkane biodegradation by a marine bacterium in the presence of an oleophilic nutrient. Biotechnol Lett 15:637-640

Robertson BR, Button DK (1989) Characterising aquatic bacteria according to population, cell size and apparent DNA content by flow cytometry. Cytometry 10:70-76

ROPME (Regional Organisation for the Protection of the Marine Environment) (1986) Evaluation of present situation on land based sources of pollution within KAP member states. Safat, Kuwait

Rosenberg E, Legmann R, Kushmaro R, Taube E, Adler E، Ron EZ (1992). Biodegradation 3:337-350

Rudd WM, Taylor CD (1980) Methane cycling in aquatic environments In: Droop MR, Jannasch HW (eds) Advances in aquatic microbiology, Vol 2. Academic Press, London, p 77-150

Scherrer P, Mille G (1989) Biodegradation of crude oil in an experimentally polluted mangrove soil. Mar Pollut Bull 20: $430-432$

Sen Gupta R, Fondeker SP, Alagarsamy R (1993) State of oil pollution in the Northern Arabian Sea after the 1991 Gulf oil spill. Mar Pollut Bull 27:85-91

Shamshoon SM, Ziara TS, Abdul-Ritha AN, Yacoub AE (1990) Distribution of oil degrading bacteria in the northwest Arabian Gulf. Mar Pollut Bull 21:38-40

Shannon MJR, Unterman R (1993) Evaluating bioremediation:distinguishing fact from fiction. A Rev Microbiol 47 : $715-738$

Singer ME, Finnerty WR (1984) Microbial metabolism of straight chain and branched alkanes. In: Atlas RM (ed) Petroleum microbiology. Macmillan, New York, p 1-60

Siron R, Pelletier D, Delille D, Roy S (1993) Fate and effect of dispersed crude oil under icy conditions simulated in mesocosms. Mar environ Res 35:273-302

Smith GC, Floodgate GD (1992) Chemical methods for estimating the concentration of methanogenic bacteria in marine cores. Cont Shelf Res 12:1187-1196

Sveum P (1987) Accidently spilled gas-oil in a shoreline sediment on Spitzbergen; natural fate and enhancement of biodegradation. In: Proceedings of the 10th Technical Seminar on the Environment, Canada, $p$ $177-192$

Tagger S, Truffant N, Le Petit J, (1990) Preliminary studies on relationships among strains forming a bacterial community selected on naphthalene from a marine sediment. Can J Microbiol 36:676-681 
Venosa AD, Haines JR, Nisameneepong W, Govind R, Pradham S, Siddique (1991a) Screening of commercial inocula for efficiency in stimulating oil degradation in closed laboratory systems. J haz Materials 28:131-144

Venosa AD, Haines JR, Allen DM (1991b) Effectiveness of commercial microbial products in enhancing oil degradation in Prince William Sound field plots In: Proceedings of 17 th Annual Hazardous Waste Conference, April 9-11. 1991. Cincinnati, Ohio

Venkateswaran K, Iwabuchi $\Upsilon$, Matsui Y, Toki H, Hamada E,
Tanaka H (1991) Distribution and biodegradation potential of oil degrading bacteria in north eastern Japanese coastal waters. FEMS Microbiol Ecol 86:113-122

Watt I, Woodhouse T, Jones DA (1993) Intertidal clean up activities and natural regeneration on the Gulf coast of Saudi Arabia from 1991 to 1992 after the 1991 Gulf oil spill. Mar Pollut Bull 27:325-331

Zarba MA, Mohammad OS, Anderlini VC, Literathy $P$, Shunbo $F$ (1985) Petroleum residues in surface sediments of Kuwait. Mar Pollut Bull 16:209-211 